\title{
Sistem Kendali Sirkulasi Udara dan Pembatasan Jumlah Pelanggan Toko Berbasis IoT
}

\author{
Labiq Al Hanif, Aditya P. P. Prasetyo, Huda Ubaya \\ Program Studi Teknik Komputer, Fakultas Ilmu Komputer, Universitas Sriwijaya, Kota Palembang, Indonesia
}

\section{ARTICLE INFORMATION}

Received: September $19^{\text {th }}, 2021$

Revised: December $28^{\text {th }}, 2021$

Available online: December $31^{\text {st }}, 2021$

\section{KEYWORDS}

Exhaust fan, Fuzzy Logic, COVID-19, IoT.

\section{CORRESPONDENCE}

Phone: +62 (0852) 68409116

E-mail: aditrecca@gmail.com

\section{A $\quad$ B $\quad \boldsymbol{S}$ T $\mathbf{T}$ A A $\mathbf{C}$ T}

The emergence of the COVID-19 pandemic in early 2020 had a major impact on human life on a global scale. Many actions and policies are aimed at anticipating transmission and breaking the chain of the spread of the COVID-19 virus, thus requiring store owners to implement various health protocols, one of them is limiting the number of customers in the store which is intended to reduce physical contact between people. This study discusses the monitoring system for the condition of the storeroom in real-time with the IoT concept, and the implementation of Sugeno fuzzy logic in controlling the speed of the exhaust fan motor to circulate air in the room and limit the number of customers during the COVID-19 pandemic based on conditions of temperature, humidity, and many people in the storeroom. The actual test results from the implementation of Sugeno fuzzy logic show that the system has good performance in calculating the number of incoming customers using two Ultrasonic sensors HC-SR04 with a distance reading error percentage of $0.82 \%$ and controlling the exhaust fan speed with an average speed of $53.9 \%$, limiting the number of customers based on the level of potential danger of COVID19 transmission automatically using a servo motor doorstop with an average control error percentage value of $2.06 \%$ and the average hazard level is $26.29 \%$.

\section{PENDAHULUAN}

Pada awal tahun 2020, kemunculan wabah penyakit jenis baru yang disebut dengan istilah Coronavirus Diseases-19 (COVID19) telah mengejutkan dunia. Kasus ini diawali pada tanggal 31 Desember 2019 dengan informasi dari World Health Organization (WHO) yang menyebutkan bahwa terdapat kluster pneumonia dengan etiologi yang tidak jelas di China, tepatnya berada di Kota Wuhan, Provinsi Hubei. Kasus ini terus berkembang sampai terjadi importasi ke luar China dan adanya laporan kematian. Hingga akhirnya WHO menetapkan COVID19 sebagai Public Health Emergency of International Concern (PHEIC) pada tanggal 30 Januari 2020 [1].

Pandemi COVID-19 berdampak besar pada kehidupan manusia dalam skala global. Banyak tindakan pengendalian yang ditujukan untuk mengurangi kontak di antara masyarakat demi memperlambat penularan virus. Serangkaian langkah telah diambil di supermarket, termasuk membatasi jumlah pelanggan, menjaga jarak sosial, dan masuk dengan kereta belanja [2]. Pemerintah indonesia juga telah mengeluarkan berbagai macam kebijakan seperti isolasi, social and physical distancing dan pembatasan sosial berskala besar (PSBB) [3]. Kebijakan tersebut berdampak pada berbagai aspek dalam kehidupan sehari-hari masyarakat, salah satunya kegiatan jual beli secara langsung yang sering kita temui di berbagai tempat seperti supermarket, resto, butik dan lain sebagainya. Sehingga menuntut pemilik toko untuk menerapkan berbagai protokol kesehatan khususnya membatasi jumlah pelanggan di dalam toko demi mendukung kebijakan pemerintah untuk mengantisipasi penularan dan memutus rantai penyebaran virus COVID-19.

Tidak hanya social distancing, sirkulasi udara juga ditekankan secara luas untuk mengendalikan penyebaran virus COVID-19 di dalam ruangan tertutup [4]. Banyak bukti menunjukkan bahwa memahami aliran udara itu penting untuk estimasi risiko tertular COVID-19 sejalan dengan data sejauh ini yang menunjukkan bahwa penularan virus yang tejadi di dalam ruangan jauh melampaui penularan yang terjadi di luar ruangan [5].

Dalam studi yang dilakukan oleh Profesor Kedokteran Hewan dan Kesehatan Masyarakat, Michael Ward dan rekan-rekannya di Universitas Sydney. Mengemukakan bahwa ketika udara lebih lembap, partikel aerosol COVID-19 akan berukuran besar dan menjadikannya seperti tetesan yang jatuh dari udara. Sedangkan pada saat udara lebih kering, partikel aerosol akan menyusut sehingga dapat bertahan di atmosfer lebih lama [6]. Sebagaimana juga dinyatakan dalam Rejimen Pengobatan COVID-19 Edisi ke6 (penerapan uji coba) yang diterbitkan oleh Komisi Kesehatan Nasional Republik Rakyat Tiongkok (2020), kemungkinan rute penularan 2019-nCoV sebagian besar adalah kontak langsung, 
transmisi droplet, dan transmisi aerosol juga merupakan jalur penularan yang memungkinkan bila ada paparan konsentrasi aerosol yang tinggi dalam tempat yang relatif tertutup dari lingkungan hidup [7]. Oleh karena itu sirkulasi udara dalam ruangan toko juga tidak kalah penting mengingat adanya kemungkinan virus ini dapat menyebar melalui udara (airborne), yaitu ketika droplet berterbangan (aerosol).

Penelitian yang dilakukan Jingyuan Wang, seorang Associate Professor di, Universitas Beihang, Beijing juga menjelaskan bahwa virus COVID-19 mirip dengan virus influenza yang cenderung lebih stabil dalam lingkungan yang memiliki suhu udara dingin dan kering [8]. Hal ini juga sejalan dengan studi yang dilakukan oleh seorang konsultan senior di Ausvet, Melanie Bannister-Tyrrell. Menunjukkan bahwa COVID-19 memiliki penyebaran yang optimum di suhu yang sangat rendah, yaitu sekitar $1^{\circ} \mathrm{C}$ sampai $9^{\circ} \mathrm{C}$. Artinya, semakin tinggi suhu, maka dugaan adanya kasus COVID-19 setiap harinya akan semakin rendah [9]. Sehingga dapat diketahui bahwasannya jika suhu dan kelembapan juga menjadi salah satu faktor yang mempengaruhi potensi penularan virus COVID-19 di dalam ruangan.

Berdasarkan permasalahan dan penelitian sebelumnya yang telah dijelaskan diatas, maka penulis merancang bangun sistem yang dapat mengendalikan kecepatan motor kipas Exhaust fan sebagai kendali sirkulasi udara dan membatasi jumlah pelanggan toko di masa pandemi COVID-19 berdasarkan persentase tingkat bahaya potensi penularan COVID-19 dalam ruangan yang ditentukan bedasarkan data suhu, kelembaban dan jumlah orang di dalam ruangan yang akan diolah mikrokontroller menggunakan kecerdasan buatan (Articial Intelligence) berbasis logika fuzzy metode Sugeno.

\section{TINJAUAN PUSTAKA}

\section{Coronavirus Diseases-19 (COVID-19}

Coronavirus Diseases-19 (COVID-19) merupakan penyakit menular yang disebabkan oleh sindrom pernapasan akut coronavirus 2 (SARS-CoV-2). Penyakit ini memiliki gejala umum yaitu batuk, sesak napas, dan demam serta gejala lain yang mungkin seperti kehilangan bau, sakit tenggorokan, nyeri otot, sakit perut, dan diare. Sementara kebanyakkan kasus hanya menyebabkan gejala ringan dan beberapa diantaranya berkembang menjadi pneumonia virus hingga kegagalan multiorgan. Virus ini pertama kali diidentifikasi pada bulan Desember tahun 2019 di Wuhan, provinsi Hubei China, dan sejak saat itu menyebar secara global hingga mengakibatkan pandemi yang saat ini sedang berlangsung[10].

\section{Sirkulasi Udara}

Sirkulasi Udara adalah sebuah proses pertukaran udara di dalam ruangan, dengan cara memasukkan udara segar ke dalam ruangan dan pembuangan udara yang pengap. Proses ini dilakukan untuk menjaga kualitas udara di dalam ruangan tersebut [11]. Sirkulasi udara di dalam ruangan atau gedung memungkinkan untuk menyaring udara di dalam ruangan sekaligus membersihkannya. Terdapat banyak cara yang dapat dilakukan untuk meningkatkan sirkulasi udara di dalam ruangan, seperti membuka jendela, meletakkan box fan di jendela, menggunakan kipas Exhaust fan, menggunakan pembersih udara portabel dan meningkatkan sistem HVAC yang sudah digunakan [12].

\section{Pembatasan Jumlah Orang}

Pembatasan jumlah orang merupakan salah satu bentuk pelaksanaan dari Pembatasan Sosial Berskala Besar (PSBB) yang dituliskan pada Peraturan Menteri Kesehatan Republik Indonesia, nomor 9 tahun 2020 Tentang Pedoman Pembatasan Sosial Berskala Besar Dalam Rangka Percepatan Penanganan Corona Virus Disease 2019 (COVID-19) yang termaktub dalam BAB III, Pasal 13 ayat 6 mengenai pembatasan kegiatan di tempat atau fasilitas umum sebagaimana dimaksud pada ayat (1) huruf C yang dilaksanakan dalam bentuk pembatasan jumlah orang dan pengaturan jarak orang [13].

\section{Arduino UNO}

Arduino adalah open-source prototyping platform yang disusun oleh mikrokontroler atau board sirkuit fisik yang dapat diprogram menggunakan software atau IDE yang berjalan di komputer. Board Arduino berinteraksi dengan lingkungan melalui komponen periferal, seperti sensor elektronik, lampu, dan motor. Kemudian, dengan menggunakan bahasa pemrograman Arduino dan Arduino Software (IDE), dimungkinkan untuk memanipulasi data yang didapat dari suatu sensor [14].

\section{Wemos D1 R2}

WeMos D1 R2 IoT adalah mikrokontroler built in Wi-Fi berbasis ESP8266EX yang diletakkan pada footprint Arduino UNO, yang berarti Wemos D1 R2 memiliki board yang terlihat dan berfungsi seperti Arduino UNO. Sehingga beberapa shield, sensor, dan perangkat keluaran yang diproduksi untuk platform Arduino akan berfungsi pada board WeMos D1 R2 dengan manfaat tambahan dari integral Wi-Fi [15].

\section{Sensor DHT11}

Sensor Suhu \& Kelembaban DHT11 menyediakan senyawa sensor suhu \& kelembaban dengan keluaran sinyal digital yang dikalibrasi. Sensor ni menggunakan metode akuisisi sinyal digital kelas tinggi dan teknologi penginderaan suhu dan kelembaban yang menjamin konsistensi yang hebat dan kemantapan jangka panjang. Sensor DHT11 terdiri dari komponen pengukuran suhu NTC dan pengukuran kelembaban tipe resistif [15].

\section{Sensor Ultrasonik HC-SR04}

Sensor ultrasonik sering digunakan untuk mendeteksi objek dan aplikasi pengukuran jarak. Pengoperasian sensor ultrasonik didasarkan pada transmisi pulsa ultrasonik dan respons waktu pulsa. Dengan cara ini, prinsip yang mendasari teknologi ini adalah bahwa kecepatan suara di udara kira-kira konstan. Dengan demikian, memperkirakan waktu refleksi pulsa memungkinkan mengetahui jarak ke objek karena hubungan proporsionalitas. Sensor ini mampu mendeteksi semua jenis objek yang memiliki reflektifitas akustik yang memadai [14].

\section{Dimmer $A C$}

Modul Dimmer AC adalah modul yang dirancang untuk mengendalikan tegangan arus $\mathrm{AC}$, yang dapat mengirimkan arus hingga 600V / 16A. Biasanya, modul Dimmer AC digunakan untuk menyalakan atau mematikan daya lampu atau elemen pemanas dan juga dapat digunakan untuk air cleaner, kipas, 
pompa dan lain sebagainya yang sering digunakan untuk sistem rumah pintar [16].

\section{Exhaust fan}

Exhaust fan adalah kipas yang berfungsi untuk mensirkulasikan udara di dalam ruangan dengan menghisap udara di dalam ruangan kemudian dibuang ke luar, dan pada saat yang bersamaan akan menarik udara segar dari luar ke dalam ruangan sehingga udara dalam ruangan tertutup dapat tersirkulasi dengan baik [17]

\section{Thinger.io}

Thinger.io adalah platform open source untuk aplikasi internet of things (IoT) dan API yang dapat menyimpan serta mengambil data menggunakan protokol HTTP berformat "protoson" (PSON) melalui internet yang memungkinkan untuk membuat aplikasi sensor logging dan social networks. Bagian terpenting dari layanan Thinger.io adalah dashboard yang berisi berbagai widget perangkat, bidang data, lokasi, dan status. Setelah membuat dashboard Thinger.io, seseorang dapat menambahkan perangkat, menulis data ke dashboard, memproses dan melihat data. Informasi dapat disajikan melalui numerik atau grafik dan juga memberikan peringatan melalui API lainnya [15].

\section{Metode Fuzzy Inference System (FIS) Sugeno}

Metode ini diperkenalkan oleh Takagi-Sugeno Kang pada tahun 1985 yang merupakan metode inferensi fuzzy untuk aturan yang direpresentasikan dalam bentuk if-then. Sistem inferensi fuzzy ini mempunyai karakteristik sendiri yaitu konsekuen, dimana output bukan merupakan himpunan fuzzy, tetapi merupakan sebuah persamaan linier dengan variabel yang sesuai dengan variabel inputnya. Terdapat dua model yang menggunakan metode TSK, yaitu model TSK orde 0 dan model TSK orde-1 [18].

\section{PERANCANGAN SISTEM}

Dari diagram blok rangkaian pada Gambar 1, dapat diketahui bahwa proses kerja alat terdiri dari tiga tahapan, yaitu input, proses (fuzzy Logic), dan output. Pada tahap input, sensor DHT11 akan mengukur suhu dan kelembaban ruangan sedangkan dua sensor Ultrasonik HCSR04 akan menghitung jumlah orang yang masuk ke dalam ruangan toko. Kemudian pada tahap proses (fuzzy logic), mikrokontroller wemos D1 R2 akan mengolah ketiga data tersebut menggunakan logika fuzzy metode Sugeno sebagai pengambil keputusan pada tahap output sistem yang berupa kendali kecepatan motor kipas Exhaust Fan dengan Dimmer AC dan kendali palang pintu toko menggunakan servo. Pada tahap output juga ketiga data akan di tampilkan melalui LCD display 20x4 dan Website Thinger.io.

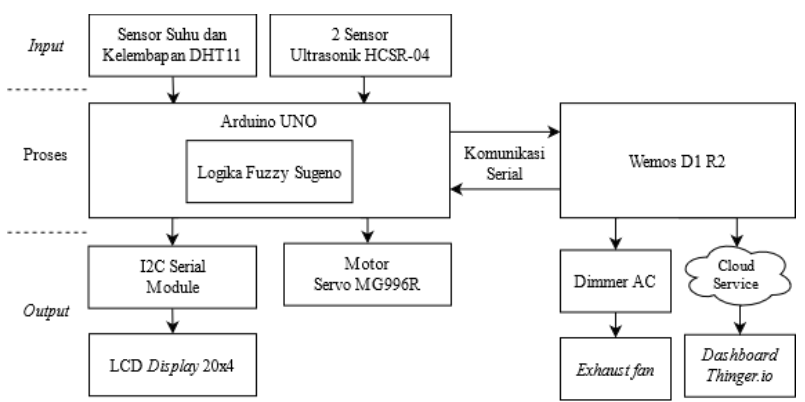

Gambar 1. Diagram Blok Rangkaian

\section{Perancangan Keseluruhan Hardware}

Pada Gambar 2 dibawah ini menunjukkan skema perancangan secara keseluruhan dari perangkat keras (Hardware) yang terdiri dari beberapa fungsi, yaitu pembacaan sensor suhu dan kelembapan DHT11, penghitungan jumlah orang masuk menggunakan sensor HC-SR04, kendali palang pintu dengan motor Servo, dan penampil data dengan LCD display 20x4 yang akan diproses oleh mikrokontoller Arduino UNO menggunakan perhitungan logika fuzzy Sugeno untuk menentukan nilai persentase kecepatan kipas motor Exhaust fan dan tingkat bahaya dari potensi penularan COVID-19.

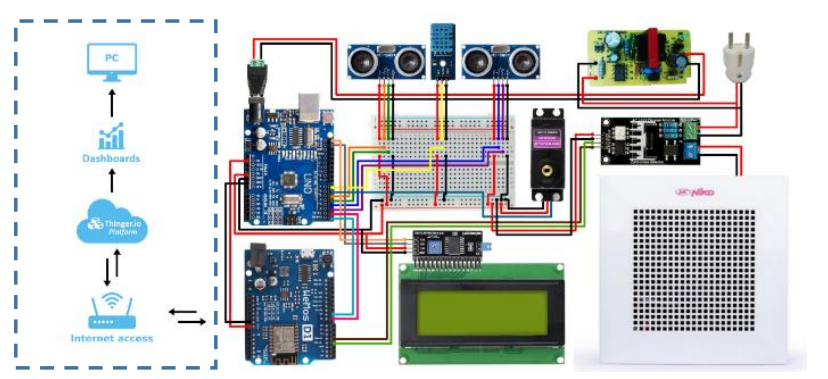

Gambar 2. Skema Rangkaian keseluruhan Hardware

Data yang telah diolah Arduino UNO akan dikirimkan ke mikrokontroller Wemos D1 R2 melalui komunikasi serial. Data tersebut akan digunakan untuk mengendalikan kecepatan motor kipas Exhaust fan menggunakan modul Dimmer AC serta dikirimkan melalui jaringan internet untuk bisa ditampilkan pada dashboard Website Thinger.io agar dapat di monitoring secara langsung.

\section{Desain Implementasi}

Pada implementasinya terdapat dua box, dimana box A (Gambar 3) akan diletakkan disamping kiri bagian luar pintu masuk ruangan, sedangkan box B (Gambar 4) diletakkan disamping kanan bagian dalam pintu masuk.

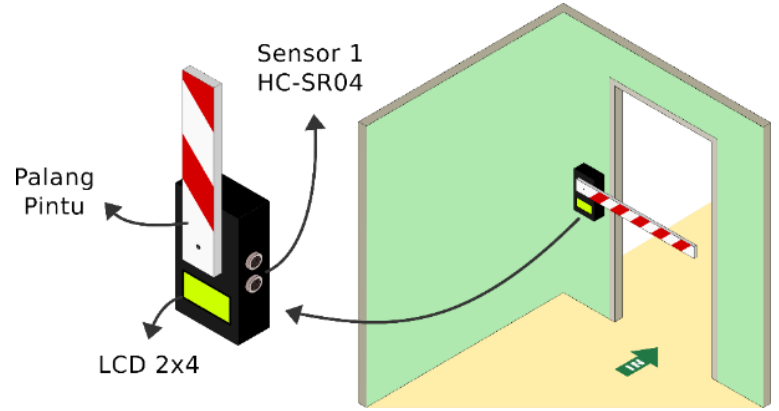

Gambar 3. Desain Implementasi Box A

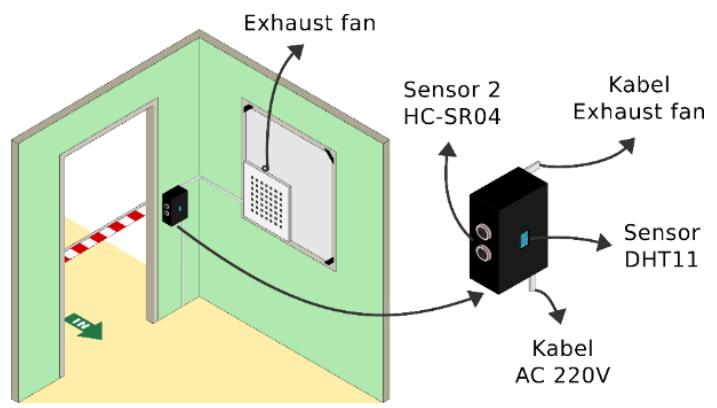


Gambar 4. Desain Implementasi Box

\section{Perancangan Logika Fuzzy Sugeno}

Logika fuzzy pada projek ini digunakan untuk menentukan dua output, yaitu kecepatan motor kipas Exhaust Fan dan menentukan persentase tingkat bahaya dari potensi penyebaran COVID-19 di dalam ruangan toko yang telah digambarkan dengan grafik singleton berikut.

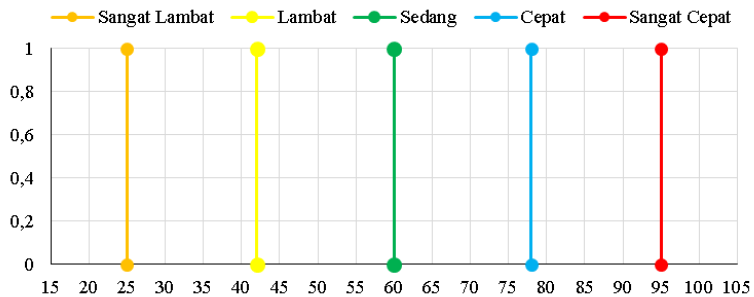

Gambar 5. Grafik Singleton Kecepatan Kipas

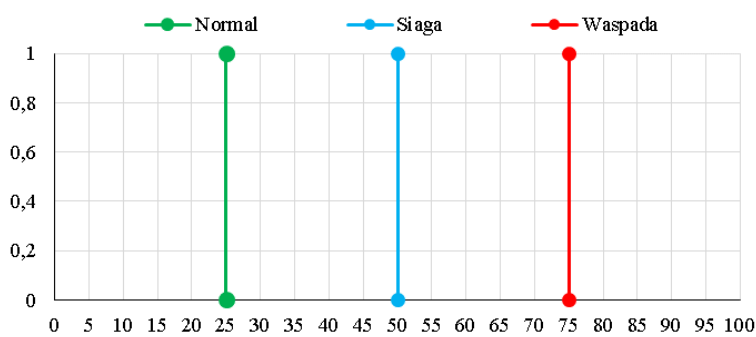

Gambar 6.Grafik Singleton Tingkat Bahaya

Dalam setiap perancangan Software dengan logika fuzzy metode Sugeno sebagai pengambil keputusan terdiri dari beberapa subproses yaitu, pembentukan himpunan fuzzy (fuzzifikasi), pembuatan basis aturan (Rule Base), penalaran (inferensi Fuzzy) dan penegasan (defuzzifikasi). Masing-masing sub-proses memiliki fungsi yang saling berhubungan, dimana output dari sub-proses akan menjadi input untuk sub-proses berikutnya sampai dengan menghasilkan output akhir dari logika fuzzy.

Dalam basis aturan untuk menentukan kecepatan motor Exhaust fan terdapat 25 rule yang dibuat berdasarkan dua variabel, yaitu suhu dan jumlah orang di dalam ruangan toko dengan 5 output, yaitu Sangat Lambat (SL), Lambat (L), Sedang (SE), Cepat (C), dan Sangat Cepat (SC) yang dapat dilihat pada Tabel 1.

Tabel 1. Basis Aturan Kecepatan Kipas

\begin{tabular}{|c|c|c|c|c|c|c|}
\hline \multirow{2}{*}{\multicolumn{2}{|c|}{ Suhu / Banyak Orang }} & \multicolumn{5}{|c|}{ Suhu } \\
\hline & & SD & D & SJ & $\mathbf{P}$ & SP \\
\hline \multirow{5}{*}{ 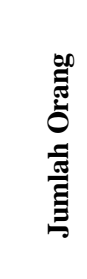 } & SSK & SL & SL & $\mathrm{L}$ & SE & $\mathrm{C}$ \\
\hline & SK & SL & $\mathrm{L}$ & $\mathrm{L}$ & SE & $\mathrm{C}$ \\
\hline & SE & $\mathrm{L}$ & $\mathrm{L}$ & SE & $\mathrm{C}$ & $\mathrm{SC}$ \\
\hline & B & $\mathrm{L}$ & SE & $\mathrm{C}$ & $\mathrm{SC}$ & $\mathrm{SC}$ \\
\hline & SB & SE & $\mathrm{C}$ & $\mathrm{SC}$ & $\mathrm{SC}$ & $\mathrm{SC}$ \\
\hline
\end{tabular}

Sedangkan pada basis aturan persentase tingkat bahaya dibuat berdasarkan tiga variabel, yaitu suhu, kelembapan, dan jumlah orang. Dimana terdapat 75 rule dengan 3 output, yaitu Normal
(N), Siaga (SI), dan Waspada (W) yang ditunjukkan pada Tabel 2 dibawah ini.

Tabel 2. Basis Aturan Tingkat Bahaya

\begin{tabular}{|c|c|c|c|c|}
\hline \multirow{2}{*}{ Suhu } & \multirow{2}{*}{ Jumlah Orang } & \multicolumn{3}{|c|}{ Kelembapan } \\
\hline & & Kering & Normal & Basah \\
\hline SD & SSK & $\mathrm{N}$ & $\mathrm{N}$ & $\mathrm{N}$ \\
\hline SD & SK & $\mathrm{N}$ & $\mathrm{N}$ & $\mathrm{N}$ \\
\hline SD & SE & SI & SI & SI \\
\hline SD & B & W & W & W \\
\hline SD & SB & W & W & W \\
\hline D & SSK & $\mathrm{N}$ & $\mathrm{N}$ & $\mathrm{N}$ \\
\hline D & SK & $\mathrm{N}$ & $\mathrm{N}$ & $\mathrm{N}$ \\
\hline D & SE & SI & SI & SI \\
\hline D & B & W & W & SI \\
\hline D & SB & W & W & W \\
\hline SJ & SSK & $\mathrm{N}$ & $\mathrm{N}$ & $\mathrm{N}$ \\
\hline SJ & SK & $\mathrm{N}$ & $\mathrm{N}$ & $\mathrm{N}$ \\
\hline SJ & SE & SI & SI & $\mathrm{N}$ \\
\hline SJ & B & SI & SI & SI \\
\hline SJ & SB & W & W & W \\
\hline $\mathbf{P}$ & SSK & $\mathrm{N}$ & $\mathrm{N}$ & $\mathrm{N}$ \\
\hline $\mathbf{P}$ & SK & $\mathrm{N}$ & $\mathrm{N}$ & $\mathrm{N}$ \\
\hline $\mathbf{P}$ & SE & SI & SI & $\mathrm{N}$ \\
\hline $\mathbf{P}$ & B & W & SI & SI \\
\hline $\mathbf{P}$ & SB & W & W & W \\
\hline SP & SSK & $\mathrm{N}$ & $\mathrm{N}$ & $\mathrm{N}$ \\
\hline SP & SK & $\mathrm{N}$ & $\mathrm{N}$ & $\mathrm{N}$ \\
\hline SP & SE & SI & SI & $\mathrm{N}$ \\
\hline SP & B & W & SI & SI \\
\hline SP & SB & W & W & W \\
\hline
\end{tabular}

Kedua tabel rule diatas terdiri dari variabel suhu dengan 5 himpunan, yaitu sangat dingin (SD), dingin (D), sejuk (SJ), panas (P), dan sangat panas (SP). Variabel kelembapan dengan 3 himpunan, yaitu kering, normal, dan basah. Variabel jumlah orang memiliki 5 himpunan yaitu sangat sedikit (SSK), sedikit (SK), sedang (SE), banyak (B), dan sangat banyak (SB).

Pada proses fuzzifikasi, nilai tegas (crisp) yang didapat dari input sensor akan diubah kedalam fungsi keanggotaan fuzzy. Tahapan fuzzifikasi pada projek ini akan menerima tiga input, yaitu input dari sensor DHT11 yang berupa data suhu dan kelembapan dan input dari sensor Ultrasonik yang berupa data jumlah orang, ketiga data input tersebut akan diubah kedalam fungsi keanggotaan fuzzy untuk mendapatkan nilai derajat keanggotaan dari masing-masing himpunan fuzzy. 


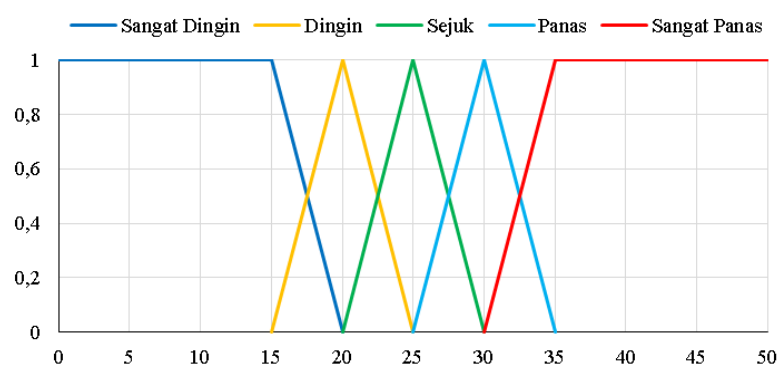

Gambar 7. Grafik Fungsi Keanggotaan Suhu

Variabel kondisi suhu dibagi menjadi lima himpunan dengan masing-masing domain himpunan fuzzy, yaitu Sangat Dingin $\left(\leq 15^{\circ} \mathrm{C}\right)$, Dingin $\left(15-25^{\circ} \mathrm{C}\right)$, Sejuk $\left(20-30^{\circ} \mathrm{C}\right)$, Panas $(25-$ $\left.35^{\circ} \mathrm{C}\right)$, dan Sangat Panas $\left(\geq 35^{\circ} \mathrm{C}\right)$. Dimana semesta pembicaraan pada model variabel suhu ruangan toko adalah $0^{\circ} \mathrm{C}$ hingga $50^{\circ} \mathrm{C}$. sebagaimana digambarkan dengan grafik fungsi keanggotaan suhu pada Gambar 7.

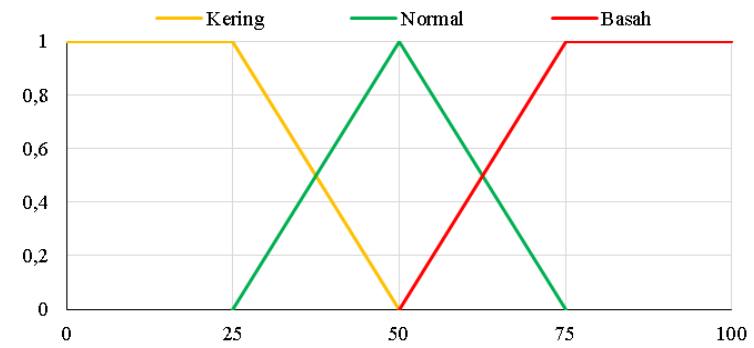

Gambar 8. Gafik Fungsi Keanggotaan Kelembaban

Variabel kondisi kelembapan pada projek ini disusun menjadi tiga himpunan dengan masing-masing domain himpunan fuzzy, yaitu Kering ( $\leq 25-50 \%)$, Normal $(25 \%-75 \%)$, dan Basah $(50 \%$ - $\geq 75 \%$ ). Dimana semesta pembicaraan model variabel kelembapan ruangan toko adalah $0 \%$ hingga $100 \%$ yang digambarkan dengan grafik pada Gambar 8 .

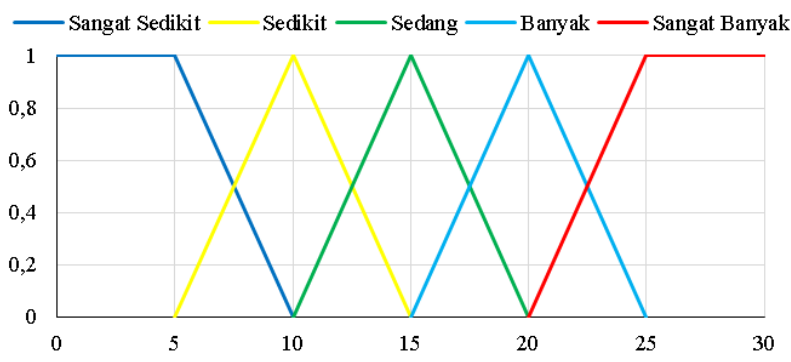

Gambar 9. Grafik Fungsi Keanggotaan Jumlah Orang

Variabel kondisi jumlah orang pada projek ini juga disusun menjadi lima himpunan dengan masing-masing domain himpunan fuzzy yaitu Sangat Sedikit $(\leq 5)$, Sedikit $(5-15)$, Sedang $(10-20)$, Banyak $(15-25)$, dan Sangat Banyak $(\geq 25)$. Dimana semesta pembicaraan pada model variabel jumlah orang adalah 0 hingga 30 orang sebagaimana digambarkan dengan grafik fungsi keanggotaan jumlah orang yang ditunjukan pada Gambar 9.

\section{Perancangan Keseluruhan Software}

Secara Keseluruhan, Software dalam projek ini dibagi menjadi dua program berdasarkan mikrokontroller yang memprosesnya.
Gambar 10 merupakan Flowchart keseluruhan program yang akan dijalankan oleh mikrokontroller Arduino UNO dan merupakan gabungan beberapa proses fungsional Software yang terfiri dari proses inisialisasi, pembacaan data sensor, proses perhitungan logika fuzzy Sugeno, Kendali motor servo sampai dengan pengiriman data ke Wemos D11 R2 melalui komunikasi serial yang telah dijelaskan sebelumnya.
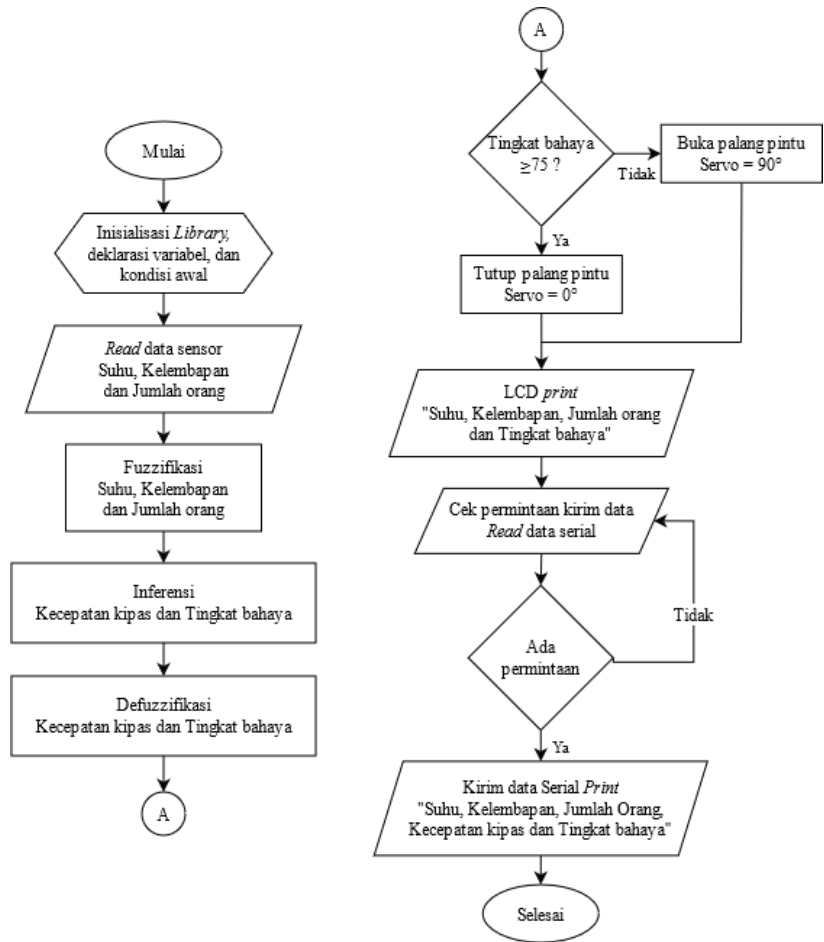

Gambar 10. Flowchart Program pada Arduino UNO

Pada Gambar 11 dibawah ini menunjukkan Flowchart keseluruhan Software yang akan dijalankan oleh mikrokontroller Wemos D1 R2 dan merupakan gabungan dari beberapa proses fungsional Software mulai dari proses Inisialisasi sampai dengan kendali kecepatan kipas Exhaust fan menggunakan modul Dimmer AC serta pengiriman data ke dashboard Thinger.io. 


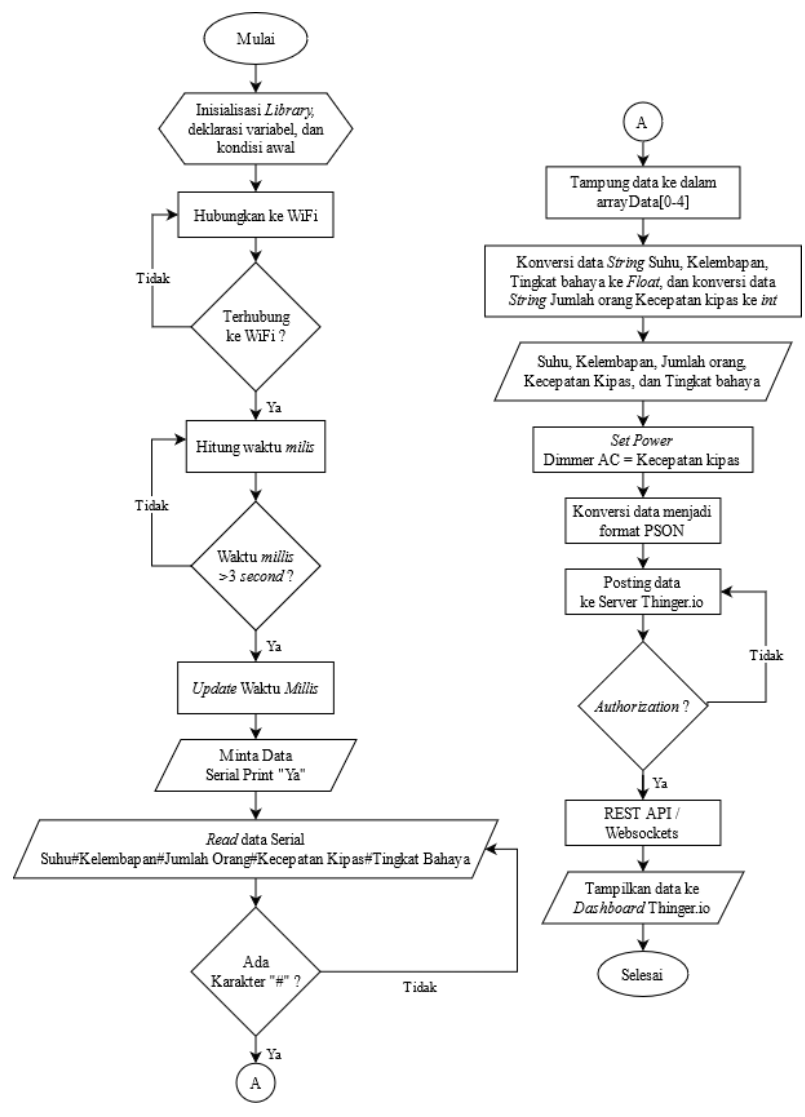

Gambar 11. Flowchart Program pada Wemos D1 R2

\section{HASIL DAN PEMBAHASAN}

Setelah semua komponen alat disusun kedalam masing-masing box, maka alat telah siap untuk diuji dan digunakan sesuai dengan tujuan awal rancang bangun. Hasil penyusunan perangkat keras secara keseluruhan ditunjukkan Gambar 12.

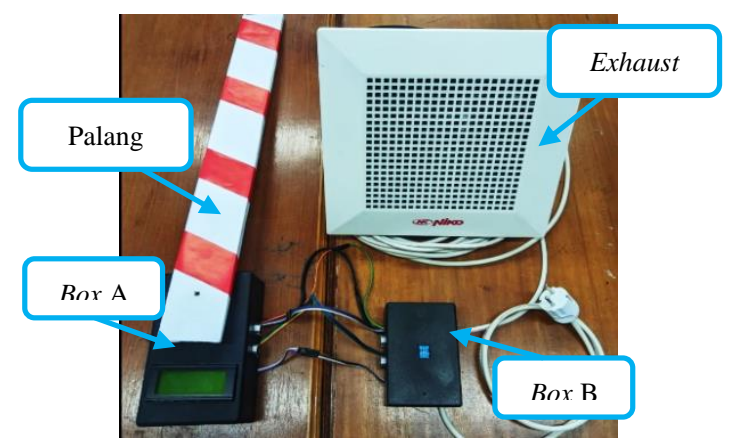

Gambar 12. Keseluruhan Alat

Gambar 13 dibawah ini menunjukkan hasil implentasi dari pemasangan box A yang di pasang pada bagian samping kiri pintu masuk ruangan uji coba, dimana box ini akan menjalankan fungsi penghitungan jumlah orang membatasi orang masuk menggunakan palang pintu.

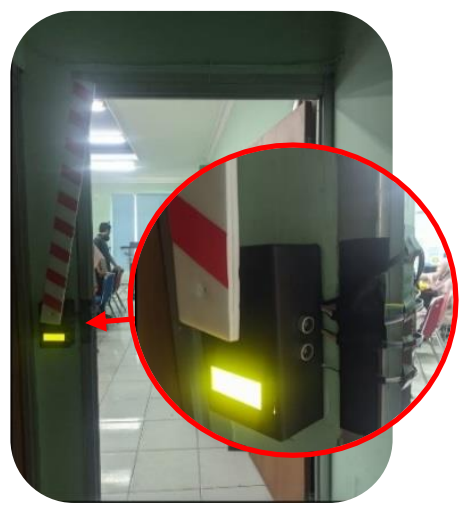

Gambar 13. Implementasi pemasangan Box A

Pada Gambar 14 dibawah ini menunjukkan hasil implementasi dari pemasangan box $\mathrm{B}$ yang dipasang pada bagian dalam pintu pada ruangan uji coba. Box ini akan menjalankan fungsi menghitung jumlah orang yang masuk serta pengukuran suhu dan kelembapan dalam ruangan.

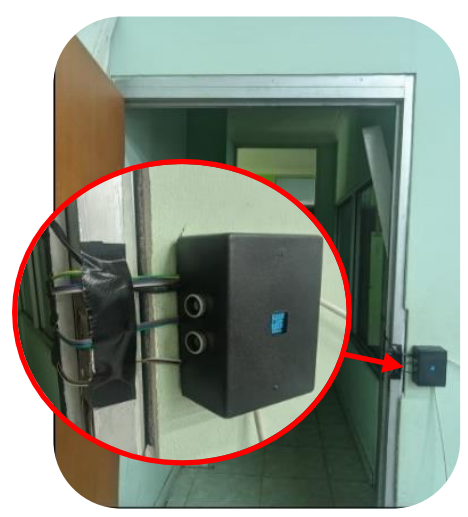

Gambar 14. Implementasi Pemasangan Box B

\section{Pengujian Sensor DHT11}

Hasil pengujian kedua sensor DHT11 dapat dilihat pada Tabel 3 yang menunjukkan perbandingan nilai hasil pembacaan data suhu dan kelembapan DHT11 dan Thermo-Hygro digital mini serta nilai rata-rata persentase error dari pembacaan sensor.

Tabel 3. Hasil pengujian sensor DHT11

\begin{tabular}{|c|c|c|c|c|c|c|}
\hline \multirow{2}{*}{$\begin{array}{l}\text { Waktu } \\
\text { (WIB) }\end{array}$} & \multicolumn{2}{|c|}{$\begin{array}{c}\text { Thermo-Hygro } \\
\text { Digital Mini }\end{array}$} & \multicolumn{2}{|c|}{ Sensor DHT11 } & \multicolumn{2}{|c|}{ Error $(\%)$} \\
\hline & $\mathbf{T}\left({ }^{\circ} \mathbf{C}\right)$ & $\mathbf{H}(\% \mathbf{R H})$ & $\mathbf{T}\left({ }^{\circ} \mathbf{C}\right)$ & $\mathbf{H}(\% \mathbf{R H})$ & $\mathbf{T}\left({ }^{\circ} \mathbf{C}\right)$ & $\mathbf{H}(\% \mathbf{R H})$ \\
\hline 13:05 & 29,8 & 58 & 30,6 & 57 & 2,68 & 1,72 \\
\hline $13: 10$ & 30,4 & 57 & 31,3 & 57 & 2,96 & 0,00 \\
\hline $13: 15$ & 30,6 & 57 & 31,8 & 57 & 3,92 & 0,00 \\
\hline $13: 20$ & 31,8 & 57 & 32,4 & 57 & 1,89 & 0,00 \\
\hline $13: 25$ & 30,5 & 57 & 31,4 & 57 & 2,95 & 0,00 \\
\hline $13: 30$ & 29 & 57 & 29,7 & 58 & 2,41 & 1,75 \\
\hline $13: 35$ & 28,2 & 58 & 29 & 58 & 2,84 & 0,00 \\
\hline $13: 40$ & 27,7 & 58 & 28,7 & 58 & 3,61 & 0,00 \\
\hline $13: 45$ & 27,9 & 57 & 28,5 & 58 & 2,15 & 1,75 \\
\hline $13: 50$ & 27,5 & 56 & 28,3 & 57 & 2,91 & 1,79 \\
\hline \multicolumn{5}{|c|}{ Rata -rata Error (\%) } & 2,71 & 0,65 \\
\hline
\end{tabular}


Dari tabel pengujian diatas dapat diketahui bahwa saat dibandingkan dengan Thremo-Hygro Digital Mini yang memiliki akurasi pengukuran suhu \pm 1 dan kelembapan $\pm 5 \%$, sensor DHT 11 mampu mengukur suhu dengan rata-rata persentase error sebesar $2,71 \%$ dan rata-rata persentase error untuk pengukuran kelembapan adalah sebesar $0,65 \%$.

Grafik garis pada Gambar 15 dibawah ini menunjukkan perbandingan perubahan nilai suhu setiap 5 menit sekali selama 45 menit mulai dari pukul 13:05 sampai dengan 14:05 antara pembacaan data suhu dari sensor DHT11 dan ThermometerHygrometer digital mini dari hasil pengujian.

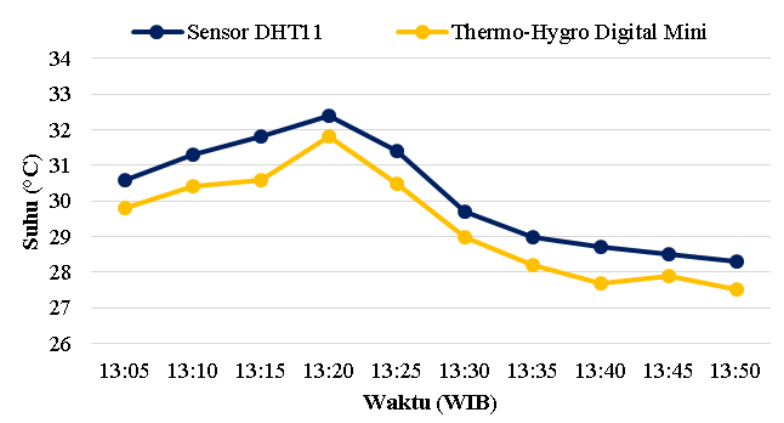

Gambar 15. Grafik Pengujian Suhu

Gambar 16 menunjukkan grafik perbandingan perubahan nilai kelembapan setiap 5 menit sekali diwaktu yang bersamaan antara pembacaan data kelembapan dari sensor DHT11 dan Thermometer-Hygrometer digital mini dari hasil pengujian.

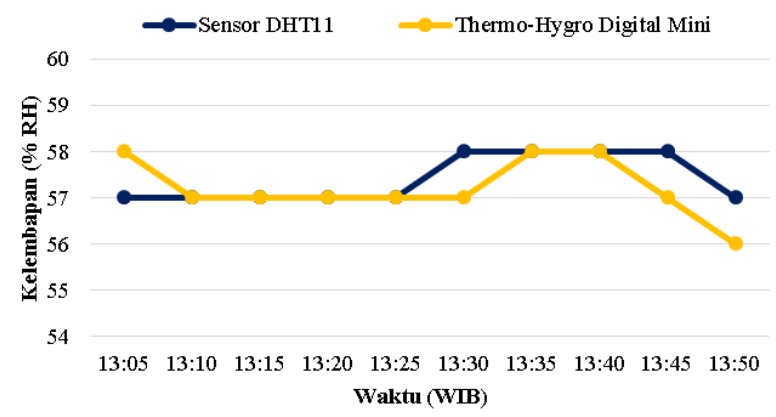

Gambar 16. Grafik Pengujian Kelembapan

\section{Pengujian Sensor Ultrasonik HC-SR04}

Hasil pengujian kedua sensor Ultrasonik dapat dilihat pada Tabel 4 dibawah ini yang menunjukkan perbandingan nilai hasil pembacaan jarak antara sensor Ultrasonik HC-SR04 dan penggaris serta nilai rata-rata persentase error dari pembacaan jarak menggunakan sensor.

Tabel 4. Hasil Pengujian Pembacaan Jarak Sensor HC-SR04

\begin{tabular}{|c|c|c|c|c|c|c|c|c|}
\hline \multicolumn{8}{|c|}{ Hasil Pengukuran Jarak (cm) } & \multirow{3}{*}{ Error $(\%)$} \\
\hline \multirow{2}{*}{ Penggaris } & \multicolumn{3}{|c|}{$\begin{array}{c}\text { Percobaan } \\
\text { Sensor 1 Ke- } \\
\end{array}$} & \multicolumn{3}{|c|}{$\begin{array}{c}\text { Percobaan } \\
\text { Sensor } 2 \text { Ke- } \\
\end{array}$} & \multirow{2}{*}{$\begin{array}{c}\text { Rata- } \\
\text { rata } \\
\text { Jarak }\end{array}$} & \\
\hline & 1 & 2 & 3 & 1 & 2 & 3 & & \\
\hline 5 & 5,00 & 4,99 & 5,05 & 5,02 & 5,10 & 5,04 & 5,03 & 0,67 \\
\hline 10 & 9,94 & 9,99 & 10,00 & 9,98 & 9,96 & 9,97 & 9,97 & 0,27 \\
\hline 24 & 24,12 & 24,09 & 24,15 & 24,00 & 24,02 & 23,97 & 24,06 & 0,24 \\
\hline 38 & 38,06 & 38,03 & 38,03 & 38,10 & 38,12 & 38,10 & 38,07 & 0,19 \\
\hline
\end{tabular}

\begin{tabular}{|c|c|c|c|c|c|c|c|c|}
\hline \multicolumn{8}{|c|}{ Hasil Pengukuran Jarak (cm) } & \multirow{3}{*}{$\operatorname{Error}(\%)$} \\
\hline \multirow{2}{*}{ Penggaris } & \multicolumn{3}{|c|}{$\begin{array}{c}\text { Percobaan } \\
\text { Sensor } 1 \text { Ke- }\end{array}$} & \multicolumn{3}{|c|}{$\begin{array}{l}\text { Percobaan } \\
\text { Sensor } 2 \text { Ke- }\end{array}$} & \multirow{2}{*}{$\begin{array}{c}\text { Rata- } \\
\text { rata } \\
\text { Jarak }\end{array}$} & \\
\hline & 1 & 2 & 3 & 1 & 2 & 3 & & \\
\hline 55 & 54,88 & 54,96 & 54,92 & 54,97 & 54,95 & 54,95 & 54,94 & 0,11 \\
\hline 76 & 74,86 & 74,88 & 74,89 & 75,00 & 74,98 & 74,88 & 74,92 & 1,43 \\
\hline 84 & 85,20 & 85,23 & 85,20 & 85,27 & 85,27 & 85,32 & 85,25 & 1,49 \\
\hline 90 & 91,20 & 91,18 & 91,22 & 91,26 & 91,30 & 91,20 & 91,23 & 1,36 \\
\hline 100 & 97,98 & 97,98 & 97,99 & 97,97 & 98,00 & 98,00 & 97,99 & 2,01 \\
\hline \multicolumn{8}{|c|}{ Rata-rata Error (\%) } & $\mathbf{0 , 8 2}$ \\
\hline
\end{tabular}

Dari tabel pengujian pengukuran jarak dengan dua sensor ultrasonik HC-SR04 pada Tabel 2, dapat diketahui bahwa Sensor Ultrasonik HC-SR04 memiliki tingkat keakuratan yang tinggi dengan persentase error yang sangat kecil, yaitu sebesar 0,82\% yang berarti sensor tersebut memiliki tingkat keberhasilan 99,18\% dalam mengukur jarak.

\section{Pengujian Modul Dimmer AC}

Hasil pengujian Dimmer AC dapat dilihat pada Tabel 5 yang menunjukkan perbandingan nilai persentase input Dimmer AC dan besaran tegangan output yang dihasilkan pada pin load.

Tabel 5. Hasil pengujian Tegangan Dimmer AC

\begin{tabular}{|c|c|c|c|c|c|c|}
\hline \multirow{2}{*}{ Input $(\%)$} & \multicolumn{5}{|c|}{ Pengukuran Tegangan (Volt) Percobaan Ke- } & \multirow{2}{*}{$\begin{array}{r}\text { Rata - } \\
\text { rata }\end{array}$} \\
\hline & 1 & 2 & 3 & 4 & 5 & \\
\hline 10 & 7,74 & 7,7 & 6,97 & 6,95 & 6,97 & 7,27 \\
\hline 20 & 22,78 & 22,86 & 22,92 & 22,98 & 23,1 & 22,93 \\
\hline 30 & 36,2 & 36,3 & 36,3 & 36,4 & 36,5 & 36,34 \\
\hline 40 & 82 & 82,4 & 82,5 & 82,1 & 82,5 & 82,30 \\
\hline 50 & 116,7 & 117 & 116,8 & 116,9 & 117 & 116,88 \\
\hline 60 & 156 & 156,2 & 156,6 & 156,4 & 156,6 & 156,36 \\
\hline 70 & 188,00 & 188,20 & 188,50 & 118,30 & 188,40 & 188,28 \\
\hline 80 & 210,2 & 210,4 & 210,3 & 210,5 & 210,5 & 210,38 \\
\hline 90 & 223,7 & 223,8 & 223,9 & 224 & 224 & 223,88 \\
\hline 100 & 228,8 & 229,9 & 230 & 229,9 & 230 & 229,72 \\
\hline
\end{tabular}

Jika diperhatikan dari kelima percobaan pada setiap nilai persentase input dalam tabel diatas menunjukkan bahwa nilai tegangan yang dihasilkan modul Dimmer AC tidaklah stabil, dimana nilai tegangan dapat terus berubah. Hasil ppercobaan pengukuran tegangan diatas juga digambarkan dengan grafik garis pada Gambar 17.

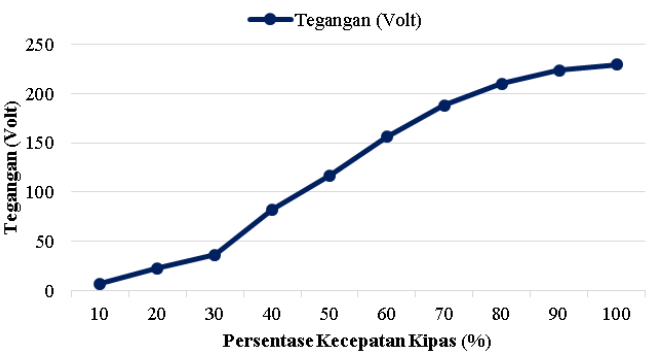

Gambar 17. Grafik Pengujian Tegangan Modul Dimmer AC 
Pada gambar grafik pengujian tegangan modul Dimmer AC diatas menunjukkan bahwa nilai output tegangan yang dihasilkan oleh modul Dimmer AC berbanding lurus dengan nilai persentase inputnya, dimana semakin besar nilai persentase inputnya, maka akan semakin besar pula output tegangan yang dihasilkan. Namun, jika dibandingkan dengan data lainnya terdapat lonjakan yang cukup besar saat nilai persentase input dinaikkan dari $30 \%$ ke $40 \%$.

Tabel 6. Hasil Pengujian Arus Modul Dimmer AC

\begin{tabular}{|c|c|c|c|c|c|c|}
\hline \multirow{2}{*}{ Input (\%) } & \multicolumn{5}{|c|}{ Pengukuran Arus (Ampere) } & \multirow{2}{*}{$\begin{array}{c}\text { Rata - } \\
\text { rata }\end{array}$} \\
\hline & 1 & 2 & 3 & 4 & 5 & \\
\hline 10 & 0,29 & 0,3 & 0,29 & 0,3 & 0,29 & 0,29 \\
\hline 20 & 0,98 & 0,99 & 0,98 & 0,99 & 0,98 & 0,98 \\
\hline 30 & 1,82 & 1,83 & 1,82 & 1,83 & 1,82 & 1,82 \\
\hline 40 & 2,69 & 2,7 & 2,69 & 2,7 & 2,69 & 2,69 \\
\hline 50 & 3,71 & 3,72 & 3,71 & 3,72 & 3,71 & 3,71 \\
\hline 60 & 4,88 & 4,89 & 4,88 & 4,89 & 4,88 & 4,88 \\
\hline 70 & 5,81 & 5,82 & 5,81 & 5,82 & 5,81 & 5,81 \\
\hline 80 & 6,45 & 6,46 & 6,45 & 6,46 & 6,45 & 6,45 \\
\hline 90 & 6,86 & 6,87 & 6,86 & 6,87 & 6,86 & 6,86 \\
\hline 100 & 7,03 & 7,04 & 7,03 & 7,04 & 7,03 & 7,03 \\
\hline
\end{tabular}

Tabel 6 menunjukkan bahwa arus yang dihasilkan dari kelima percobaan pada setiap nilai persentase input modul Dimmer AC memiliki nilai yang cukup stabil, dimana tidak terdapat perubahan yang begitu signifikan. Kemudian agar dapat dianalisis lebih mudah, nilai rata-rata dari setiap pengukuran arus juga digambarkan dengan grafik garis pada Gambar 18.

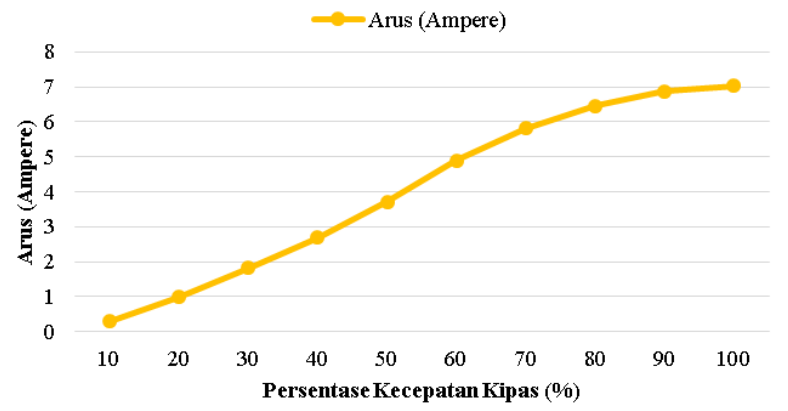

Gambar 18. Grafik Pengujian Arus Dimmer AC

Gambar grafik pengujian arus pada modul Dimmer AC diatas juga menunjukkan bahwa nilai output arus yang dihasilkan oleh modul Dimmer AC berbanding lurus dengan nilai persentase inputnya, dimana semakin besar nilai persentase inputnya, maka akan semakin besar pula output arus yang dihasilkan.

Dari kedua hasil pengujian tersebut dapat diketahui bahwa tegangan dan arus yang dihasilkan oleh modul Dimmer AC linier dengan nilai persentase inputnya, Sehingga Modul Dimmer AC dapat digunakan untuk mengendalikan kecepatan kipas Exhaust fan. Semakin besar nilai persentase inputnya, maka akan semakin besar pula tegangan dan arus yang dihasilkan dan semakin cepat pula putaran motor kipas Exhaust fan.

\section{Pengujian Motor Servo MG996R}

Hasil pengujian motor servo MG996R dapat dilihat pada Tabel 7 yang menunjukkan perbandingan nilai input derajat dalam program dan hasil output yang diukur dengan busur serta nilai rata-rata persentase error dari kendali motor servo.

Tabel 7. Hasil Pengujian Motor Servo MG996R

\begin{tabular}{cccc}
\hline \multirow{2}{*}{ No. } & \multicolumn{2}{c}{ Derajat Motor Servo } & Error\% \\
\cline { 2 - 3 } & Input $\left({ }^{\circ}\right)$ & Output $\left({ }^{\circ}\right)$ & \\
\hline 1 & 0 & 0 & 0 \\
2 & 5 & 5 & 0 \\
5 & 15 & 15 & 0 \\
4 & 20 & 19 & 5,26 \\
5 & 25 & 25 & 0 \\
6 & 55 & 54 & 1,85 \\
7 & 65 & 63 & 3,17 \\
8 & 70 & 67 & 4,48 \\
9 & 85 & 83 & 2,41 \\
10 & 90 & 87 & 3,45 \\
\hline
\end{tabular}

Tabel hasil pengujian diatas menunjukkan bahwa motor servo MG996R mampu bergerak ke arah yang ditentukan dengan ratarata nilai persentase error yang kecil, yaitu sebesar $2,06 \%$ saat dibandingkan dengan nilai derajat sebenarnya yang terukur menggunakan busur.

\section{Pengujian LCD Display 20x4}

Pengujian dilakukan dengan melakukan pengamatan dari hasil output display LCD 20x4 yang telah di program sebelumnya untuk menampilkan beberapa karakter huruf, angka, dan simbol. Hasil pengujian LCD dapat dilihat melalui Gambar 19 yang menunjukkan output yang ditampilkan layar LCD display 20x4 yang telah diprogram sebelumnya untuk menampilkan karakter huruf, angka, dan simbol.

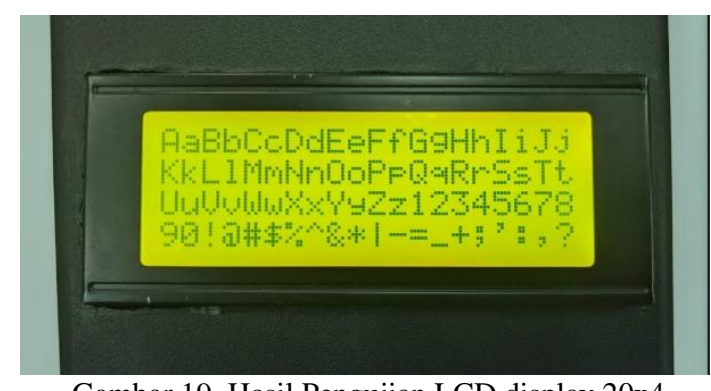

Gambar 19. Hasil Pengujian LCD display 20x4

\section{Pengujian Komunikasi Serial}

Pengujian ini bertujuan untuk mengetahui apakah komunikasi serial yang digunakan untuk mengirimkan hasil olahan data dari mikrokontroller Arduino UNO ke Wemos D1 R2 dapat dilakukan. Sehingga Wemos D1 R2 dapat mengirim data tersebut untuk ditampilkan pada dashboard Thinger.io. 
Pengujian ini dilakukan dengan mengamati hasil output serial monitor Wemos D1 R2 yang menampilkan data yang diterima dari mikrokontroller Arduino UNO setiap tiga detik sekali sesuai dengan permintaan.

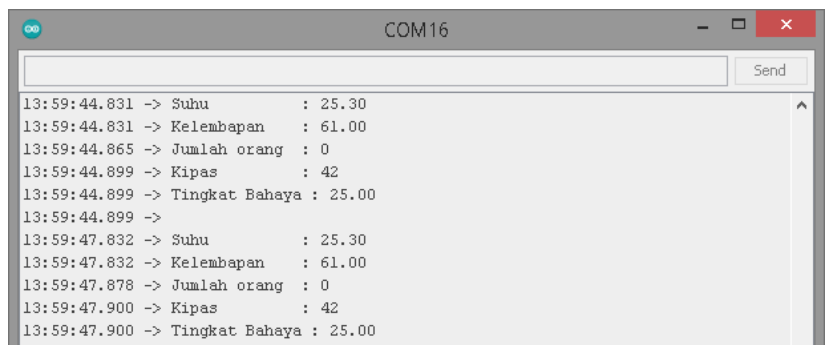

Gambar 20. Hasil Pengujian Komunikasi Serial

Gambar 20 diatas menunjukkan hasil pengujian komunikasi serial antara kedua mikrokontroller dengan melakukan pengamatan pada output serial monitor Wemos D1 R2. Dari gambar 4.10 dapat diketahui bahwa komunikasi serial antara kedua mikrokontroller telah berhasil dilakukan, dimana data akan terbaca dan ditampilkan ke serial monitor hanya saat ada permintaan data dari mikrokontroller Wemos D1 R2, yaitu setiap tiga detik sekali.

\section{Pengujian Power Supply}

Pengujian ini dilakukan dengan mengukur nilai tegangan DC yang dihasilkan adaptor menggunakan multimeter digital. Pada Gambar 21 dibawah ini menunjukkan hasil pengukuran tegangan pada power supply menggunakan multimeter digital yang menunjukan output tegangan DC sebesar 12,11 Volt.

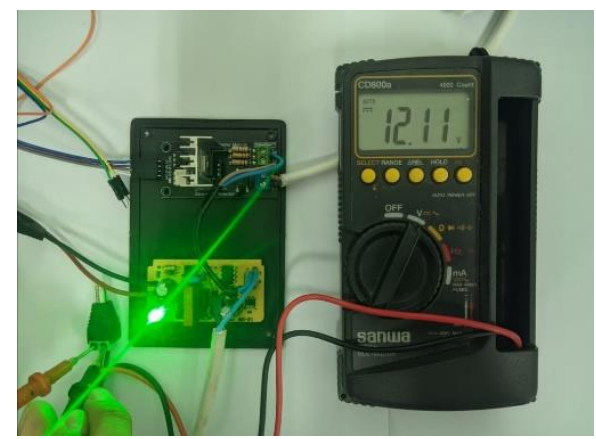

Gambar 21. Proses Pengukuran Tegangan Power Supply

Dengan demikian, nilai tegangan tersebut dapat digunakan sebagai power supply untuk mikrokontroller Arduino UNO sehingga dapat mencapai kestabilan. Karena Arduino UNO dapat beroperasi pada kisaran tegangan 5 Volt sampai dengan 12 Volt.

\section{Pengujian Alat Penghitung Jumlah Orang Masuk}

Hasil pengujian penghitungan jumlah orang masuk menggunakan dua sensor Ultrasonik dapat dilihat pada Tabel 8 yang menunjukkan persentase keberhasilan alat dalam lima kemungkinan skenario yang terjadi saat seseorang atau lebih mengakses pintu, antara lain:

1) Satu orang masuk atau keluar dari dalam ruangan.

2) Satu orang masuk dan satu lainnya keluar dari dalam ruangan.

3) Dua orang masuk ke dalam ruangan dalam waktu yang bersamaan.
4) Dua orang masuk atau keluar dari ruangan dalam interval waktu yang singkat.

5) Satu orang masuk dan satu lainnya keluar dari ruangan dalam interval waktu yang singkat

Tabel 8. Hasil Pengujian Penghitungan Jumlah Orang Masuk

\begin{tabular}{|c|c|c|c|c|c|c|c|c|c|c|c|}
\hline \multirow{2}{*}{ Skenario } & \multicolumn{10}{|c|}{ Percobaan Ke- } & \multirow{2}{*}{$\begin{array}{c}\text { Keberhasilan } \\
(\%)\end{array}$} \\
\hline & 1 & 2 & 3 & 4 & 5 & 6 & 7 & 8 & 9 & 10 & \\
\hline 1 & $\checkmark$ & $\checkmark$ & $\checkmark$ & $x$ & $\checkmark$ & $\checkmark$ & $\checkmark$ & $x$ & $\checkmark$ & $\checkmark$ & 80 \\
\hline 2 & $x$ & $x$ & $x$ & $x$ & $x$ & $x$ & $x$ & $x$ & $x$ & $x$ & 0 \\
\hline 3 & $x$ & $x$ & $x$ & $x$ & $x$ & $x$ & $x$ & $x$ & $x$ & $x$ & 0 \\
\hline 4 & $\checkmark$ & $x$ & $\checkmark$ & $\checkmark$ & $\checkmark$ & $\checkmark$ & $x$ & $x$ & $\checkmark$ & $\checkmark$ & 70 \\
\hline 5 & $x$ & $\checkmark$ & $x$ & $\checkmark$ & $\checkmark$ & $x$ & $x$ & $x$ & $\checkmark$ & $\checkmark$ & 50 \\
\hline
\end{tabular}

Pada tabel hasil pengujian diatas, simbol " $\checkmark$ " menunjukkan bahwa percobaan berhasil sedangkan simbol " $\boldsymbol{x}$ ” menunjukkan bahwa percobaan yang dilakukan gagal. Sehingga dapat diketahui bahwa alat $\mathrm{p}$ enghitung jumlah orang masuk menggunakan dua sensor ultrasonik cukup efektif digunakan untuk mendeteksi satu orang yang masuk atau keluar dari ruangan. Hal ini ditunjukkan pada skenario pertama dan keempat dengan tingkat keberhasilan masing-masing sebesar $80 \%$ dan $70 \%$, namun sangat tidak efektif jika digunakan untuk mendeteksi dua orang yang masuk atau keluar dari ruangan dalam waktu yang bersamaa yang ditunjukkan pada skenario dua dan tiga dengan tingkat keberhasilan sebesar 0\%. Kemudian kurang efektif jika digunakan untuk mendeteksi orang pada skenario 5 dengan tingkat keberhasilan sebesar $50 \%$. .

\section{Pengujian Fungsional Logika Fuzzy Sugeno}

Pengujian fungsional logika fuzzy dilakukan dengan mengambil 20 sampel hasil output perhitungan fuzzy dari sistem yang diimplementasikan pada ruangan uji coba selama lebih kurang empat jam mulai pukul 11:00 WIB sampai dengan 15:00 WIB.

Hasil pengujian fungsional logika fuzzy digambarkan kedalam grafik garis yang menunjukkan perbandingan dan perubahan dari nilai variabel suhu, kelembapan, jumlah orang, kecepatan kipas Exhaust fan dan tingkat bahaya dari potensi penularan COVID19 dalam ruangan uji coba terhadap waktu selama pengujian berlangsung.

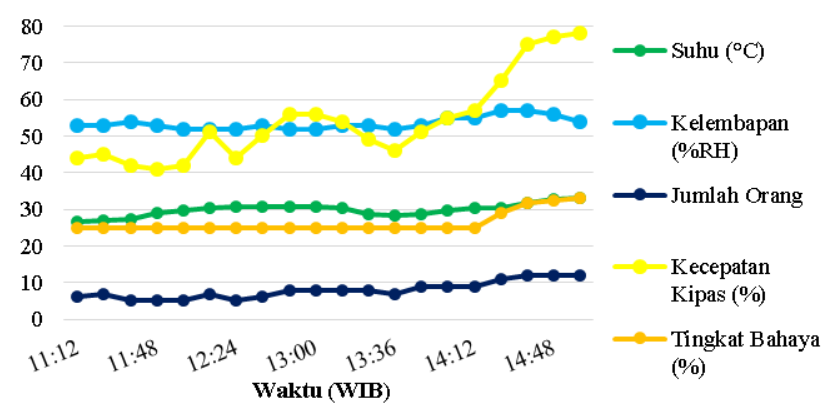

Gambar 22. Grafik Pengujian Fungsional Logika Fuzzy

Dari gambar 22 dapat diketahui bahwa persentase kecepatan motor kipas Exhaust fan proporsional satu sama lain dengan kondisi suhu dan jumlah orang di dalam ruangan yang menunjukkan bahwa kecepatan kipas akan meningkat dan 
menurun seiring dengan peningkatan dan penurunan suhu dan jumlah orang dalam ruangan. Tingkat bahaya juga menunjukkan hubungan yang proporsional dengan variabel suhu, kelembapan dan jumlah orang, dimana persentase tingkat bahaya naik dari $28,4 \%$ sampai dengan $33,05 \%$ saat terjadi peningkatan jumlah orang dari 9 menjadi 12 dan suhu dari $30,3^{\circ} \mathrm{C}$ menjadi $33,2^{\circ} \mathrm{C}$ serta penurunan kelembapan dari $57 \%$ menjadi $54 \%$.

Melalui pengujian tersebut juga didapatkan data yang menunjukkan titik-titk pemetaan dari rule apa saja yang aktif berdasarkan kondisi ruangan dari sampel yang telah diambil saat pengujian dilakukan, dari Gambar 23 dibawah ini dapat diperhatikan bahwa selama empat jam pengujian terdapat dua dari 8 rule kecepatan kipas yang aktif memiliki frekuensi terbesar, yaitu rule 4 dan 9 dengan frekuensi sebanyak 16 kali. Hal ini dikarenakan rata-rata suhu ruangan selama pengujian adalah $29,85^{\circ} \mathrm{C}$ dengan rata-rata jumlah orang sebanyak 8 orang. Sehingga menunjukkan bahwa kondisi ruangan sedang dalam keadaan panas dan terdapat sedikit orang.

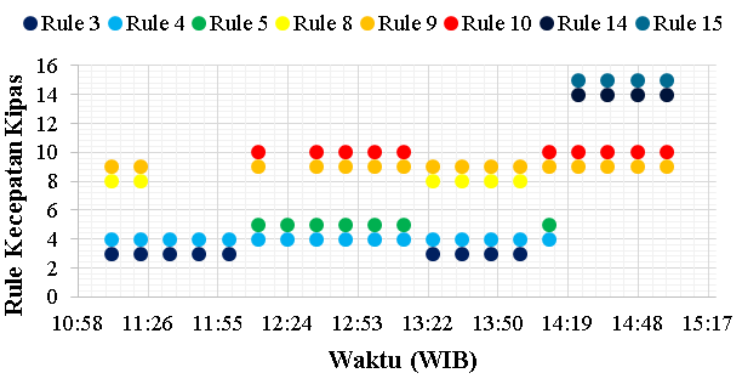

Gambar 23. Titik Pemetaan Rule Kecepatan Kipas yang Aktif

Sedangkan Gambar 24 dibawah ini menunjukkan bahwa terdapat total 19 rule tingkat bahaya yang aktif, dimana rule 47 dan 48 memiliki frekuensi terbesar yang muncul sebanyak 16 kali. Hal ini dikarenakan rata-rata suhu dan kelembapan ruangan selama pengujian adalah sebesar $29,85^{\circ} \mathrm{C}$ dan $53,55 \%$ dengan rata-rata jumlah orang sebanyak 8 orang. Sehingga menunjukkan bahwa ruangan memiliki suhu yang panas, kelembapan yang normal dan terdapat sedikit orang didalamnya.

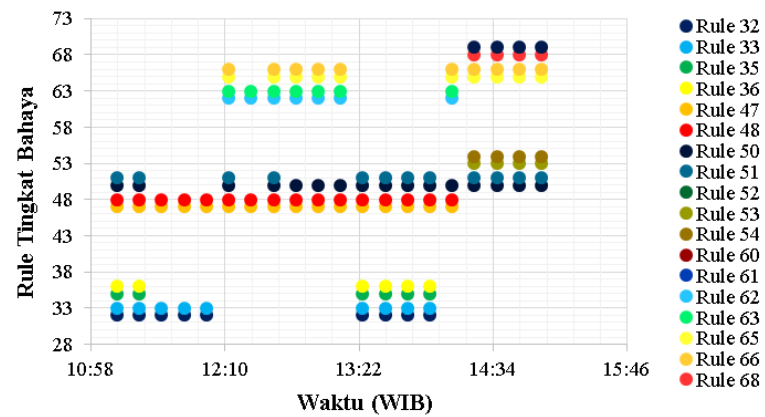

Gambar 24. Titik Pemetaan Rule Tingkat Bahaya yang Aktif

Hasil pengujian ini menunjukkan bahwa logika fuzzy metode Sugeno yang telah dirancang dan diimplementasikan dapat bekerja dengan baik sesuai dengan tujuan perancangan untuk menentukan kecepatan kipas Exhaust fan dan tingkat bahaya dari potensi penularan COVID-19 berdasarkan kondisi suhu, kelembapan dan jumlah orang dalam ruangan toko.

\section{Pengujian Monitoring Data Menggunakan Thinger.io.}

Hasil pengujian monitoring data menggunakan Thinger.io dapat dilihat melalui Gambar 25 yang menunjukkan bahwa data suhu, kelembapan, jumlah orang, persentase kecepatan kipas Exhaust fan dan tingkat bahaya dari potensi penularan COVID-19 di dalam ruangan toko dapat dimonitoring melalui dashboard website Thinger.io dengan konsep Internet of Things (IoT).

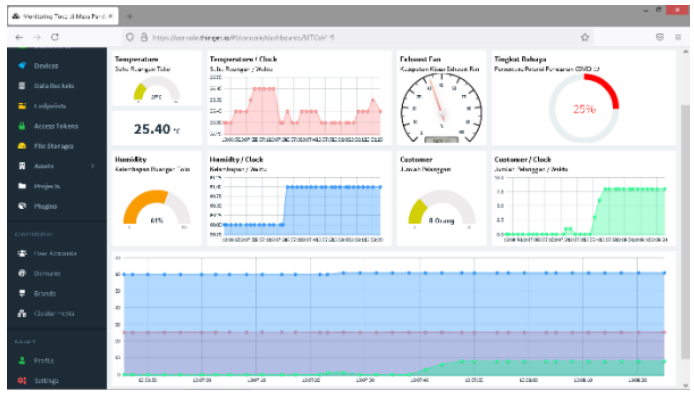

Gambar 25. Hasil Monitoring Data pada Dashboard Thinger.io

Setelah itu, untuk mengetahui apakah data tersebut dapat dimonitoring secara real time, maka dilakukan pengambilan data untuk mengetahui waktu delay hingga data dapat ditampilkan dan dimonitor melalui dashboard website Thinger.io. Adapun hasil pengujian ditunjukkan pada Tabel 9 dibawah ini.

Tabel 9. Hasil Pengujian Waktu Delay Thinger.io

\begin{tabular}{|c|c|c|c|}
\hline \multirow{2}{*}{ Data Ke- } & \multicolumn{2}{|c|}{ Waktu Data di Tampilkan (WIB) } & \multirow{2}{*}{$\begin{array}{c}\text { Delay } \\
\text { (Second) }\end{array}$} \\
\hline & Alat & Thinger.io & \\
\hline 1 & 13:59:02 & 13:59:05 & 3 \\
\hline 2 & 13:59:06 & 13:59:09 & 3 \\
\hline 3 & 13:59:11 & 13:59:12 & 1 \\
\hline 4 & 13:59:11 & $13: 59: 14$ & 3 \\
\hline 5 & 13:59:17 & $13: 59: 18$ & 1 \\
\hline 6 & $13: 59: 20$ & 13:59:20 & 0 \\
\hline 7 & $13: 59: 23$ & $13: 59: 23$ & 0 \\
\hline 8 & $13: 59: 26$ & $13: 59: 26$ & 0 \\
\hline 9 & $13: 59: 29$ & $13: 59: 30$ & 1 \\
\hline 10 & $13: 59: 32$ & $13: 59: 32$ & 0 \\
\hline 11 & $13: 59: 35$ & $13: 59: 36$ & 1 \\
\hline 12 & $13: 59: 38$ & 13:59:39 & 1 \\
\hline 13 & 13:59:41 & $13: 59: 42$ & 1 \\
\hline 14 & $13: 59: 44$ & $13: 59: 44$ & 0 \\
\hline 15 & 13:59:47 & $13: 59: 47$ & 0 \\
\hline 16 & 13:59:50 & 13:59:50 & 0 \\
\hline 17 & $13: 59: 53$ & 13:59:54 & 1 \\
\hline 18 & 13:59:56 & 13:59:56 & 0 \\
\hline 19 & $13: 59: 59$ & 13:59:59 & 0 \\
\hline 20 & 14:00:02 & 14:00:03 & 3 \\
\hline & Rata-ra & & 0,95 \\
\hline
\end{tabular}


Dari tabel pengujian di atas dapat diketahui bahwa Platform Thinger.io dapat digunakan untuk melakukan monitorig data secara real time melalui website berbasis Internet of Things (IoT) dengan rata-rata delay kurang dari satu detik, yaitu selama 0,95 detik dengan delay terlama selama 3 detik.

\section{KESIMPULAN}

Setelah melalui proses yang panjang mulai dari rancang bangun, implementasi sampai dengan mendapatkan data hasil pengujian dan analisa dari alat, terdapat beberapa hal yang dapat disimpulkan, yaitu sebagai berikut:

Mengukur suhu dan kelembapan ruangan toko dapat dilakukan dengan menggunakan sensor DHT11 yang memiliki rata-rata persentase error dari pembacaan suhu sebesar $2,71 \%$ dan rata-rata persentase error untuk pengukuran kelembapan adalah sebesar 0,65\% saat dibandingkan dengan Thremo-Hygro Digital Mini yang memiliki akurasi pengukuran suhu \pm 1 dan kelembapan \pm $5 \%$.

Menghitung jumlah orang di dalam ruangan dapat dilakukan dengan memanfaatkan dua sensor Ultrasonik HC-SR04 yang memiliki tingkat keakuratan yang tinggi dalam mengukur jarak dengan persentase error yang sangat kecil, yaitu sebesar $0,82 \%$ yang berarti sensor tersebut memiliki tingkat keberhasilan 99,18\%. Kedua sensor cukup efektif digunakan untuk mendeteksi satu orang yang masuk atau keluar dari ruangan. Namun sangat tidak efektif jika digunakan untuk mendeteksi dua orang yang masuk atau keluar dari ruangan dalam waktu yang bersamaan.

Perancangan dan implementasikan logika fuzzy metode Sugeno terdiri dari tiga proses, yaitu proses pembentukkan himpunan fuzzy (fuzzifikasi), penalaran (inferensi), dan penegasan (defuzzifikasi). Pada proses fuzzifikasi berisi 3 varabel linguistik, yaitu suhu, kelembapan, dan jumlah orang. Variabel suhu memiliki 5 himpunan, yaitu sangat dingin, dingin, sejuk, panas, dan sangat panas. Variabel kelembapan memiliki 3 himpunan, yaitu kering, normal, dan basah. Variabel jumlah orang memiliki 5 himpunan yaitu sangat sedikit, sedikit, sedang, banyak, dan sangat banyak. Pada proses inferensi digunakan 25 rule untuk menentukan kecepatan motor kipas dan 75 rule untuk menentukan tingkat bahaya. Kemudian pada proses defuzzifikasi menggunakan metode weight avarage.

Sistem mampu mengendalikan kecepatan motor kipas Exhaust fan secara otomatis menggunakan modul Dimmer AC dengan input nilai persentase kecepatan kipas mulai dari 0 sampai dengan $100 \%$ berdasarkan hasil output perhitungan logika fuzzy yang telah dirancang. Semakin besar nilai persentase inputnya, maka akan semakin besar pula tegangan dan arus yang dihasilkan dan semakin cepat pula putaran motor kipas Exhaust fan.

Sistem dapat membatasi jumlah pelanggan toko dimasa pandemi COVID-19 dengan menggerakkan palang pintu menggunakan motor servo yang memiliki rata-rata nilai persentase error kendali yang kecil sebesar $2,06 \%$. Servo akan menjadi aktuator palang pintu untuk membuka dan menutup secara otomatis berdasarkan persentase tingkat bahaya dari potensi penularan COVID-19. Jika tingkat bahaya $\geq 75 \%$ maka palang pintu akan menutup dan jika tidak maka palang akan tetap terbuka secara otomatis.
Monitoring ruangan toko dimasa pandemi COVID-19 secara real time dapat dilakukan dengan menggunakan Platform Thinger.io melalui website berbasis Internet of Things (IoT) dengan rata-rata delay sebesar 0,95 second. Kemudian, selama empat jam pengujian implementasi alat di ruangan uji coba didapatkan nilai rata-rata suhu sebesar 29,85, rata-rata kelembapan sebesar 53,55, rata-rata jumlah orang sebanyak 8 orang, rata-rata kecepatan kipas Exhaust fan sebesar 53,9\% dan rata-rata tingkat bahaya sebesar $26,29 \%$.

\section{DAFTAR PUSTAKA}

[1] Kementrian KesehatanRI, "Pedoman Kesiapan Menghadapi COVID-19,” pp. 0-115, 2020.

[2] Q. Xu and M. Chraibi, "On the effectiveness of the measures in supermarkets for reducing contact among customers during COVID-19 period," Sustain., vol. 12, no. 22, pp. 1-14, 2020.

[3] N. K. Astini, "Pemanfaatan Teknologi Informasi dalam Pembelajaran Tingkat Sekolah Dasar pada Masa Pandemi Covid-19," LAMPUHYANG, vol. 11, no. 2 SEArticles, Jul. 2020.

[4] C. Sun and Z. Zhai, "The efficacy of social distance and ventilation effectiveness in preventing COVID-19 transmission," Sustain. Cities Soc., vol. 62, no. June, p. 102390, 2020.

[5] R. K. Bhagat, M. S. Davies Wykes, S. B. Dalziel, and P. F. Linden, "Effects of ventilation on the indoor spread of COVID-19," J. Fluid Mech., vol. 903, 2020.

[6] Jawapos.com, "Kelembapan Udara Dikatakan Pengaruhi Penyebaran Virus Korona,” 2020. [Online]. Available:

https://www.jawapos.com/kesehatan/25/08/2020/kelem bapan-udara-dikatakan-pengaruhi-penyebaran-viruskorona/. [Accessed: 15-Jan-2021].

[7] Z. Ge, L. Yang, J. Xia, X. Fu, and Y. Zhang, "Possible aerosol transmission of COVID-19 and special precautions in dentistry," J. Zhejiang Univ. B, vol. 21, no. 5, pp. 361-368, 2020.

[8] Liputan6.com, "Penjelasan Mengenai Pengaruh Suhu Udara Terhadap Virus Corona Covid-19," 2020. [Online].

Available: https://www.liputan6.com/bola/read/4219468/penjelasa n-mengenai-pengaruh-suhu-udara-terhadap-viruscorona-covid-19. [Accessed: 15-Jan-2021].

[9] A. Nursalikah, "Seberapa Besar Pengaruh Suhu Terhadap Virus Corona?," republika.co.id, 2020. [Online]. Available: https://republika.co.id/berita/q89dcl366/seberapa-besarpengaruh-suhu-terhadap-virus-corona. [Accessed: 15Jan-2021].

[10] M. Khairudin, S. Yatmono, I. M. Nashir, F. Arifin, W. Aulia, and Widyantoro, "Exhaust Fan Speed Controller Using Fuzzy Logic Controller," J. Phys. Conf. Ser., vol. 1737, no. 1, 2021.

[11] WHO, "Tanya Jawab: Ventilasi dan Pengaturan Suhu Udara (AC) dalam konteks COVID-19."

[12] Covid.RI.gov, "Preventing the Spread of COVID-19 By Circulating Air in Schools and Other Buildings." [Online]. Available: https://covid.ri.gov/covid-19prevention/indoor-air-circulation. [Accessed: 24-May- 
2021].

[13] PERATURAN MENTERI KESEHATAN NO.9, PERATURAN MENTERI KESEHATAN TENTANG PEDOMAN PEMBATASAN SOSIAL BERSKALA BESAR DALAM RANGKA PERCEPATAN PENANGANAN CORONA VIRUS DISEASE 2019. 2020, pp. 9-19.

[14] B. F. Carvalho, C. C. M. Silva, A. M. Silva, F. Buiati, and R. Timóteo, "Evaluation of an arduino-based IoT person counter," IoTBD 2016 - Proc. Int. Conf. Internet Things Big Data, no. IoTBD, pp. 129-136, 2016.

[15] R. Vithlani, S. Fultariya, M. Jivani, and H. Pandya, “An open source Real Time IOT based environmental sensor monitoring system,” vol. 2, pp. 145-138, 2018.

[16] RobotDyn.com, "AC Light Dimmer Module, 1 Channel, $3.3 \mathrm{~V} / 5 \mathrm{~V}$ logic, AC 50/60hz, 220V/110V." [Online]. Available: https://robotdyn.com/ac-light-dimmermodule-1-channel-3-3v-5v-logic-ac-50-60hz-220v110v.html. [Accessed: 16-Apr-2020].

[17] R. M. Iqbal, "RANCANG BANGUN INSTALASI GAS BUANG DI BENGKEL OTOMOTIF FAKULTAS TEKNIK UNIVERSITAS NEGERI YOGYAKARTA," Yogyakarta, 2019.

[18] A. Naba, Belajar Cepat Fuzzy Logic Menggunakan Matlab. Yogyakarta: Graha Ilmu, 2009. 